\title{
PENGARUH PERBEDAAN KONSENTRASI LARUTAN ASAM ASETAT TERHADAP NILAI KEKUATAN GEL, VISKOSITAS, KADAR PROTEIN, DAN RENDEMEN GELATIN KULIT SAPI
}

\author{
Indriani Wewengkang, M. Sompie, S.E. Siswosubroto, J.H.W. Pontoh
}

Fakultas Peternakan Universitas Sam Ratulangi Manado. 95115

\begin{abstract}
ABSTRAK
Penelitian ini telah dilakukan dengan tujuan untuk mengkaji pengaruh perbedaan konsentrasi larutan asam asetat terhadap nilai kekuatan gel, viskositas, kadar protein dan rendemen gelatin kulit sapi. Materi yang digunakan dalam penelitian ini adalah kulit sapi dan larutan asam asetat. Penelitian ini menggunakan rancangan acak lengkap (RAL) 4x4 dengan perlakuan larutan asam asetat ( $1 \%$, $3 \%, 5 \%$ dan $7 \%$ ), masing-masing perlakuan diulang sebanyak 4 kali. Variabel yang diamati adalah kekuatan gel, viskositas, kadar protein dan nilai rendemen gelatin kulit sapi. Hasil penelitian menunjukkan bahwa penambahan larutan asam asetat memberikan pengaruh yang berbeda tidak nyata $(P>0,05)$ terhadap nilai kekuatan gel dan rendemen gelatin kulit sapi, tetapi terhadap nilai viskositas dan kadar protein menunjukkan pengaruh yang berbeda nyata $(\mathrm{P}<0,05)$. Kesimpulan yang diperoleh adalah penambahan larutan asam asetat 3\% menghasilkan kekuatan gel, viskositas, kadar protein dan nilai rendemen gelatin yang baik.
\end{abstract}

Kata Kunci : Asam asetat, Gelatin, Kulit sapi

*korespondensi (corresponding author)

Email: meitysompie@yahoo.com

\section{ABSTRACT}

\section{THE EFFECT OF DIFFERENT CONCENTRATION OF ACETIC ACID SOLUTION ON THE GEL STRENGTH, VISCOSITY, PROTEIN CONTENT AND RENDEMEN VALUE}

This research conducted to determine the effect of different concentration of acetic acid solution on the gel strength, viscocity, protein content and rendemen of cow skin gelatin. The material used cowskin and acetic acid solution. This study used Completely Randomized Design (CRD). The treatments were concentration of acetic acid solution $(1 \%, 3 \%, 5 \%$ and $7 \%)$ and four replicates of treatment. The result showed that the different concetration of acetic acid solution had no significant effect $(\mathrm{P}>0.05)$ to the gel strength and rendemen value of gelatin, but it had significant effect $(\mathrm{P}<0.05)$ on viscosity and protein content of cow skin gelatin. It was concluded that acetic acid solution $3 \%$ had the best gel strength, viscosity, protein content and rendemen value of cow skin gelatin.

Keywords: Acetic acid, Cow skin, Gelatin

\section{PENDAHULUAN}

Kulit merupakan salah satu hasil ikutan pemotongan ternak (by product) yang mempunyai nilai ekonomi yang tinggi. 
Kulit sapi dapat dimanfaatkan untuk pembuatan produk pangan hasil ternak yakni gelatin. Potensi ternak sapi di Indonesia khususnya di Sulawesi Utara mengalami peningkatan. Pada tahun 2015 populasi ternak sapi sebanyak 119.744 ekor, tahun 2016 sebanyak 129.215 ekor dan pada tahun 2017 mencapai 133.177 ekor (Badan Pusat Statistik Provinsi Sulawesi Utara, 2017). Data tersebut menunjukkan bahwa potensi pemanfaatan kulit sapi sebagai bahan baku pembuatan gelatin cukup menjanjikan. Pemanfaatan kulit sapi sebagai bahan baku pembuatan gelatin dari bahan baku kulit sapi hasil sisa penyamakan (Sugihartono, 2014) dan dari kulit sapi bali dengan menggunakan perendaman larutan kapur (Mokoolang et al., 2019) telah dilakukan. Kulit tersusun hampir $80 \%$ senyawa organik yaitu protein. Oleh karena itu, pemanfaatan kulit sebagai bahan baku perlu dikembangkan.

Gelatin adalah suatu produk yang berbentuk hidrokoloid yang berasal dari hasil hidrolisis protein kolagen hewan atau ternak (Said, 2012), bersifat hidrofilik yang banyak terdapat pada kulit, tulang dan jaringan hewan seperti pada sapi dan babi. Gelatin juga merupakan senyawa turunan yang dihasilkan dari serabut kolagen jaringan penghubung yang dihidrolisis dengan asam atau basa. Gelatin dalam produk pangan dapat dimanfaatkan sebagai bahan makanan misalnya sebagai agen pembentuk gel, pengental, pengemulsi, pembentuk busa dan sebagai pelapis atau edible coating pada daging, pada produk non pangan sebagai kapsul lunak dan keras, sebagai penutup luka, kosmetik, dan fotografi (Hanani et al., 2012, Sompie et al., 2017).

Kebutuhan gelatin di dalam negeri setiap tahun meningkat namun industri yang secara khusus memproduksi gelatin di Indonesia belum tersedia sehingga masih memproduksi gelatin dari negara lain. Pemanfaatan gelatin dalam industri pangan dan non pangan yang semakin luas mengakibatkan terjadinya peningkatan penggunaan gelatin sehingga untuk memenuhi ketersedian gelatin, Indonesia mengimpor gelatin dari negara Jepang, India, Brazil, Jerman dan Cina (Said et al., 2011). Penggunaan larutan asam asetat dalam pembuatan gelatin telah digunakan beberapa peneliti antara lain, gelatin dari bahan baku kulit itik (Yusnaini, 2003), gelatin dari kulit babi (Sompie et al., 2012), kulit kambing (Said et al., 2011), dengan lama perendaman asam asetat $\left(\mathrm{CH}_{3} \mathrm{COOH}\right) \quad 0,5-2 \%$, gelatin kulit kaki ayam dengan kosentrasi 3\% (Pantow et al., 2015). Penelitian sebelumnya telah dilakukan beberapa peneliti dengan memproduksi gelatin dari beberapa bahan baku antara lain: dari tulang sapi 
(Yuniarifin et al., 2006), tulang ikan $\left(\mathrm{CH}_{3} \mathrm{COOH}\right) 0,5-2 \%$, gelatin kulit kaki $\left(\mathrm{CH}_{3} \mathrm{COOH}\right)$ 0,5-2\%, gelatin kulit kaki ayam dengan kosentrasi 3\% (Pantow et al., 2015). Penelitian sebelumnya telah dilakukan beberapa peneliti dengan memproduksi gelatin dari beberapa bahan baku antara lain: dari tulang sapi (Yuniarifin et al., 2006), tulang ikan (Gomez and Montero, 2001; Marzuki et al., 2011), kulit ikan tuna (Agustin et al., 2015), kulit kaki ayam (Ulfah, 2011; Sarbon et al., 2013; Sompie et al., 2015), kulit domba (Hasdar dan Rahmawati, 2017), kulit babi (Sompie et al., 2012), kulit kaki itik (Kuan et al., 2016), kulit kaki ayam broiler (Rareset al 2017), dan dari ceker ayam kampung (Asmudrono et al., 2019).

Pemanfaatan kulit sapi sebagai bahan baku pembuatan gelatin di Sulawesi Utara belum banyak diteliti. Selain itu kulit sapi di Sulawesi Utara khususnya memiliki potensi yang besar tapi belum dimanfaatkan secara optimal, kulit sapi tersebut umumnya hanya dimanfaatkan untuk pembuatan kerupuk kulit.

Perendaman dalam larutan asam dilakukan untuk membengkakkan kulit lebih cepat, sehingga pada saat terekstraksi srtuktur kolagen lebih mudah terurai. Kolagen yang dihidrolisis oleh larutan asam lebih banyak dari pada larutan basa dengan menggunakan waktu yang sama, karenaitu perendaman dalam larutan basa membutuhkan waktu yang lebih lama untuk menghidrolisis kolagen (Ward dan Court, 1977). Berdasarkan uraian di atas, telah dilakukan suatu penelitian dengan tujuan untuk mengkaji pengaruh penambahan larutan asam asetat $\left(\mathrm{CH}_{3} \mathrm{COOH}\right)$ pada pembuatan gelatin kulit sapi terhadap kekuatan gel, viskositas, kadar protein dan rendemen.

\section{MATERI DAN METODE PENELITIAN}

\section{Waktu dan tempat penelitian}

Penelitian telah dilaksanakan pada bulan Januari sampai Februari 2020 di Laboratorium Teknologi Hasil Ternak Jurusan Produksi Ternak Fakultas Peternakan Universitas Sam Ratulangi Manado.

\section{Materi Penelitian}

Bahan yang digunakan dalam penelitian ini adalah kulit sapi yang diambil di RPH Manado, larutan asam asetat, aquades dan kapur $\mathrm{Ca}(\mathrm{HO})_{2}$. wadah 
plastik, saringan, waterbath, toples untuk perendaman, gelas ukur, cetakan (wadah pengeringan), oven dan lemari pendingin, Stromer Viscosimeter Behlin CSR-10.

\section{Metode Penelitian}

Penelitian ini menggunakan Rancangan Acak Lengkap (RAL) dengan 4 perlakuan dan 4 ulangan (Steel dan Torrie 1993). Perlakuan adalah penambahan asam asetat:

$$
\begin{aligned}
& \mathrm{P}_{1}=1 \% \text { asam asetat } \\
& \mathrm{P}_{2}=3 \% \text { asam asetat } \\
& \mathrm{P}_{3}=5 \% \text { asam asetat } \\
& \mathrm{P}_{4}=7 \% \text { asam asetat }
\end{aligned}
$$

\section{Variabel Penelitian:}

\section{Kekuatan Gel}

Uji kekuatan gel dilakukan menurut metode Muyonga et al. (2004), dengan cara bubuk gelatin dilarutkan dalam aquades pada suhu $60^{\circ} \mathrm{C}$ dengan kosentrasi larutan $6,67 \%$ w/v. Larutan yang terbentuk dimasukan dalam wadah kemudian disimpan pada suhu $5^{0} \mathrm{C}$ selama 16-18 jam. Sampel yang telah siap diuji diletakkan dalam plunger $(\mathrm{d}=13 \mathrm{~mm})$ pada suhu $10^{\circ} \mathrm{C}$. Hasil pembacaan gaya maksimal yang diberikan plunger penetrasi dalam gel $10 \mathrm{~mm} /$ menit sedalam $4 \mathrm{~mm}$. perhitungan nilai kekuatan gel dilakukan dalam satuan g bloom. Rumus yang digunakan mengkonversikan F. max dalam satuan
$\mathrm{N} / \mathrm{cm}^{2}$ (dyne/ $\mathrm{cm}^{2}$ ) ke $\mathrm{g}$ Bloom adalah dengan persamaan ;

Kekuatan gel $(\mathrm{g}$ Bloom $)=20+2,86.10^{-3} \mathrm{D}$ Keterangan :

D $\left(\right.$ Dyne $\left./ \mathrm{cm}^{2}\right)=$ F/Gx 980

$\mathrm{F}=$ Tinggi grafik sebelum patah

$\mathrm{G}=$ konstanta $(0,07)$

\section{Viskositas}

Uji viskositas dilakukan menurut metode Anersen et al. (2005) dengan cara bubuk gelatin dilarutkan dalam aquadest pada suhu $60{ }^{\circ} \mathrm{C}$ dengan konsentrasi larutan 6,67\% w/v (6,67 g sampel $100 \mathrm{~mL}$ aquades). Larutan gelatin dituang ke alat sejenis mangkuk yang sebelumnya telah diberi air pada bagian luar mangkuk untuk mengontrol pergerakkan temperature sampel. Pengujian dilakukan pada suhu kamar $28^{\circ} \mathrm{C}$. Nilai viskositas diukur dengan Stromer Viscosimeter Behlin CSR10. Pencatatan waktu yang ditempuh spindle dalam 1 kali putaran dilakukan sebanyak 3 kali untuk selanjutnya di ratarata.

\section{Kadar Protein}

Kadar protein kasar dalam sampel dengan mengalikan $\mathrm{N}$ yang dihasilkan dengan faktor pengali 5,55. Metode ini didasarkan pada oksidasi komponen nitrogen gelatin dengan asam sulfat, sehingga diperoleh amonium sulfat. Setelah larutan dibuat alkalis dengan $\mathrm{NaOH}$, amonium didestilasi dan ditangkap 
dengan asam borat sehingga terbentuk garam. Menentukan jumlah amonium yang terdestilasi dilakukan titrasi garam yang terbentuk dengan $\mathrm{HCl}$. Persentase nitrogen dan kadar protein kasar dihitung menggunakan rumus:

kadar nitrogen $=\frac{(m l H C L-\text { ml blanko }) \times N \text { HCL } x 14,007}{\text { berat contoh kering }(m g)} \times 100 \%$

Kadar Protein Kasar $=\% \mathrm{~N}$ x 5,55 (Schrieber dan Gareis, 2007)

\section{Rendemen}

Rendemen diperoleh dari perbandingan antara berat gelatin kering yang dihasilkan dengan berat bahan segar (Wulandari et al., 2013:). Besarnya rendemen dapat diperoleh dengan rumus:

Rendemen $(\%)=\frac{\text { Berat gelatin }}{\text { Berat } \text { kulit }} \times 100 \%$

\section{Prosedur Penelitian}

Proses pembuatan gelatin dari kulit sapi menurut metode Mokoolang et al. (2019) adalah sebagai berikut: Pertama tama penyiapan bahan baku, pembersihan kulit sapi yang telah dipisahkan dari daging, lemak dan bulu dengan cara membakar dan dihilangkan bulu dengan menggunakan pisau. Hal ini bertujuan untuk menghilangkan sebagian dari lemak yang berlebihan dan kotoran-kotoran yang menempel pada kulit agar bisa terlepas, sehingga tidak mengganggu proses berikutnya kemudian dicuci bersih dengan air mengalir, kulit dipotong ukuran 3-4 cm lalu dicuci dengan air suling sampai bersih, setelah itu kulit ditimbang. Tahapan pertama sebanyak 200 gram setiap ulangan. Kulit sapi dipotong-potong kecil selanjutnya direndam dalam larutan kapur $\mathrm{Ca}(\mathrm{OH})_{2}$ selama 48 jam, perendaman dengan $\mathrm{Ca}(\mathrm{OH})_{2}$ tujuannya agar kulit mudah lunak. Setelah itu dicuci dengan air mengalir sampai bersih. Proses selanjutnya dilanjutkan dengan perendaman dalam beberapa konsentrasi larutan asam asetat yakni $1 \%, 3 \%, 5 \%$ dan $7 \%$ (sebagai perlakuan) kemudian disimpan dalam lemari pendingin dengan suhu $4^{0} \mathrm{C}$ selama 24 jam. Perendaman dalam larutan asam asetat bertujuan untuk memudahkan proses swelling (proses pembengkakan) yakni serabut-serabut kolagen berubah menjadi serat yang lebih kecil sehingga kulit menjadi longgar dan membengkak sehingga memudahkan prose ekstraksi. Selanjutnya dilakukan ekstraksi suhu $55^{\circ} \mathrm{C}$ selama 5 pada waterbath, setelah itu larutan gelatin hasil ekstraksi disaring dengan kain dan dituang kewadah yang sudah dilapisi plastik, selanjutnya dikeringkan didalam oven dengan suhu $60^{\circ} \mathrm{C}$ selama 48 jam. Lembaran gelatin yang diperoleh kemudian dihaluskan dengan menggunakan blender dan disimpan dalam deksikator dan selanjutnya dianalisa. 


\section{HASIL DAN PEMBAHASAN}

Data rataan pengaruh penambahan larutan asam asetat pada pembuatan gelatin kulit sapi terhadap kekuatan gel, viskositas, kadar protein dan rendemen dapat dilihat pada pada Tabel 1

\section{Kekuatan Gel}

Hasil analisis sidik ragam menunjukkan bahwa penambahan larutan asam dalam pembuatan gelatin kulit sapi memberikan pengaruh yang berbeda tidak nyata $(\mathrm{P}>0,05)$ terhadap nilai kekuatan gel Dengan pengertian bahwa nilai kekuatan gel gelatin yang dihasilkan secara statistik sama pada perlakuan konsentrasi asam asetat, meskipun berdasarkan Tabel 1 nilai kekuatan gel yang dihasilkan cenderung menurun dengan bertambahnya konsentrasi asam asetat. Menurunnya nilai kekuatan gel tersebut disebabkan terjadinya proses pemutusan rantai polimer asam amino dengan bertambahnya konsentrasi asam, sehingga ikatan antara molekul-molekul polimer penyusun kolagen terpecah menjadi rantai monomer yang sagat pendek dan mengalami kerusakan, sehingga proses pembentukkan gel menjadi berkurang (Sompie et al., 2014). Kekuatan gel sangat penting dalam menentukan perlakuan terbaik dalam proses ekstraksi gelatin karena salah satu sifat penting gelatin adalah mampu mengubah cairan menjadi semi padat atau mengubah sol menjadi gel (Kolodziejska et al., 2003). Rataan kekuatan gel gelatin kulit sapi yang dihasilkan dari penelitian ini berkisar antara 71,8-74,85 g Bloom, tidak jauh berbeda dengan hasil penelitian sebelumnya oleh Pantow et al. (2016) dan Sompie et al. (2019) yakni 61,15 - 68,29 g Bloom dan masih memenuhi standar industri gelatin yakni $50-300$ g Bloom (GMIA, 2012).

Tabel 1. Rataan Karakteristik Gelatin Kulit Sapi.

\begin{tabular}{|c|c|c|c|c|}
\hline \multirow{2}{*}{ Variabel } & \multicolumn{4}{|c|}{ Konsentrasi Asam Asetat } \\
\hline & $1 \%$ & $3 \%$ & $5 \%$ & $7 \%$ \\
\hline Kekuatan gel (g Bloom) & $74,85 \pm 3,17$ & $73,85 \pm 0,51$ & $73,25 \pm 1,17$ & $71,8 \pm 1,17$ \\
\hline Viskositas (cP) & $2,55 \pm 0,05^{\mathrm{b}}$ & $2,57 \pm 0,05^{\mathrm{b}}$ & $2,22 \pm 0,05^{\mathrm{a}}$ & $2,52 \pm 0,15^{\mathrm{b}}$ \\
\hline Kadar protein $(\%)$ & $86,47 \pm 0,16^{\mathrm{b}}$ & $84,24 \pm 0,18^{a}$ & $85,89 \pm 0,67^{b}$ & $84,63 \pm 0,32^{\mathrm{a}}$ \\
\hline Rendemen & $10,52 \pm 1,01$ & $10,88 \pm 1,12$ & $11,52 \pm 0,63$ & $11,72 \pm 0,42$ \\
\hline
\end{tabular}

Keterangan: Superskrip yang berbeda pada baris yang sama menunjukan perbedaan yang nyata $(\mathrm{P}<0,05), \mathrm{Sd}=$ Standar deviasi . 


\section{Viskositas}

Hasil analisis sidik ragam menunjukkan bahwa konsentrasi asam asetat dalam pembuatan gelatin kulit sapi memberikan pengaruh yang berbeda nyata $(\mathrm{P}<0,05)$, terhadap viskositas gelatin. Hasil uji Duncan menunjukkan bahwa nilai viskositas gelatin kulit sapi dengan konsentrasi asam asetat 3\% nyata lebih tinggi dari 1\%, 5\%, dan 7\%. Begitu juga dengan kosentrasi asam asetat 1\% lebih tinggi dari $5 \%$ dan $7 \%$ tetapi lebih rendah dari 3\%. Gelatin kulit sapi yang menggunakan kosentrasi asam asetat 5\% lebih rendah dari yang menggunakan konsentrasi asam asetat 1\%, 3\%, dan $7 \%$. Hal ini berarti bahwa konsentrasi asam asetat 3\% lebih tinggi dari semua perlakuan. Tingginya viskositas berhubungan dengan berat molekul gelatin dan panjang rantai asam aminonya (Ulfah, 2011). Gelatin dengan kandungan hidroksi prolin yang tinggi, mempunyai sifat viskoelastik yang tinggi (Gomez et al., 2002). Rataan viskositas gelatin kulit sapi yang dihasilkan dari penelitian ini berkisar antara 2,22 - 2,57 cP. Nilai viskositas ini masih memenuhi standar yang ditetapkan GMIA (2012) yaitu $1,5-7,5 \mathrm{cP}$.

\section{Kadar Protein}

Hasil analisis sidik ragam menunjukkan bahwa konsentrasi asam asetat dalam pembuatan gelatin kulit sapi memberikan pengaruh yang berbeda nyata $(\mathrm{P}<0,05)$, terhadap kadar protein. Hasil uji Duncan menunjukan bahwa kadar protein gelatin kulit sapi dengan konsentrasi asam asetat $1 \%$ nyata lebih tinggi dari pada konsentrasi asam asetat 3\%, 5\% dan $7 \%$. Selanjutnya konsentrasi asam asetat 5\% lebih tinggi dari konsentrasi asam asetat $3 \%$ dan $7 \%$ tetapi lebih rendah dari konsentransi $1 \%$. Demikian juga gelatin kulit sapi yang menggunakan konsentrasi asam asetat 3\% lebih rendah dari 1\%, 5\%, dan $7 \%$. Hal ini menunjukkan bahwa semakin rendah nilai konsentrasi asam asetat yang digunakan maka semakin tinggi nilai kadar protein gelatin kulit sapi. Pada konsentrasi asam yang tinggi terjadi penurunan kadar protein, hal ini disebabkan karena asam asetat akan menghidrolisis ikatan peptida lebih kuat sehingga terjadi kehilangan protein pada saat pencucian kulit sapi. Perendaman dalam larutan asam asetat menyebabkan protein struktural terutama kolagen akan mengalami pengembang sehingga struktur koil terbuka (Ulfah, 2011). Rataan kadar protein gelatin kulit sapi pada penelitian ini adalah 84,24 - 86,47\%. Hasil ini masih memenuhi standar gelatin yang dihasilkan seperti yang dilaporkan oleh Oktaviani et al. (2017) bahwa kadar protein gelatin kulit sapi adalah 85,68\%. 


\section{Rendemen}

Hasil analisis sidik ragam menunjukkan bahwa konsentrasi asam asetat dalam pembuatan gelatin kulit sapi memberikan pengaruh yang berbeda tidak nyata $(\mathrm{P}>0,05)$, terhadap nilai rendemen. Artinya nilai rendemen gelatin kulit sapi sama pada semua konsentrasi asam asetat meskipun pada Tabel terlihat nilai rendemen meningkat dengan semakin bertambahnya konsentrasi asam asetat. Dengan kata lain semakin tinggi konsentrasi asam asetat maka akan mempengaruhi nilai rendemen gelatin kulit sapi. Menurut Kolodziejska et al. (2007) terjadi peningkatan rendemen berkaitan dengan banyaknya jumlah kolagen yang dikonversi dan mengalami transformasi menjadi gelatin. Hal ini lebih diperjelas oleh Sompie et al. (2020) bahwa semakin tinggi konsentrasi asam asetat maka nilai rendemen akan semakin meningkat. Semakin banyak rendemen yang dihasilkan maka semakin efisien perlakuan yang diterapkan. Menurut Haris (2008) jumlah nilai rendemen dipengaruhi oleh konsentrasi larutan asam asetat yang digunakan dalam perendaman. Peningkatan rendemen berkaitan dengan jumlah kolagen yang terkonversi menjadi gelatin.

Rataan rendemen gelatin kulit sapi pada penelitian berkisar antara 10,52-
11,72\%. Hasil rendemen ini masih termasuk pada kisaran kisaran normal gelatin (Pantouw et al., 2015 dan Mokoolang et al., 2019).

\section{KESIMPULAN}

Penambahan larutan asam asetat 3\% menghasilkan kekuatan gel, viskositas, kadar protein dan nilai rendemen gelatin yang baik

\section{DAFTAR PUSTAKA}

Agustin, A. T. dan M. Sompie. 2015. Kajian gelatin kulit ikan tuna (Thunnus albacares) yang diproses menggunakan asam asetat. Prosiding Seminar Nasional Masyarakat Biodiversitas Indonesia, 1(5):1186 1189. ISSN 2407-8050.

Anersen, J. A. dan A. Gilberg. 2005. Ekstraction and characterization of gelatin from Atlantic Salmon (Salmosar) skin. Bioresource Technology 98 (1) :53-57.

Asmudrono, S., M. Sompie, S.E. Siswosubroto, J. A. D. Kalele. 2019. Pengaruh perbedaan konsentrasi gelatin ceker ayam kampung terhadap karakteristik fisik edible film.Zootec 39(1): 64 -70.

BPS. 2017. Statistik Populasi Ternak Sapi Di Sulawesi Utara. http:// sulut.bps.go.id. Diakses November 2018. 
GMIA. 2012. Gelatin Handbook Gelatin Manufactures Institute Of America. Inc., New York, NY.

Gomez, G. M. C. dan P. Montero. 2001. Extraction of gelatin from megrim (Lepidorhombus boscil) Skin With Several Organic Acids. J Food Sci. 66 (2): 213-216

Hanani, N.Z.A., Y. H. Roos, dan J. P Kerry. 2012. Use of beef, pork and fish gelatin sources in the manufacture of films and assessment of ther composition andmechanical properties. Food Hydrocolloids 29(1): 144-151.

Hasdar, M. dan Y. D. Rahmawati 2017. Kajian potensi kulit domba asal brebes sebagai bahan dasar produksi gelatin halal. Jurnal Aplikasi Teknologi Pangan (6): 1-6.

Haris, M.A. 2008. Pemanfaatan limbah tulang ikan nila (Oreochromis niloticus) sebagai gelatin dan pengaruh lama penyimpanan pada suhu ruang. Skripsi, Fakultas Perikanan dan Kelautan. Institut Pertanian Bogor.

Kołodziejska, I., E. Skierka, M. Sadowska, W. Kołodziejski, dan C. Niecikowska. 2008. Effect of extracting time and temperature on yield of gelatin from different fishoffal. J. Food Chem. 107:700706.

Kuan, Y. H., A. M. Nafchi, N. Huda, F. Arifin, dan A. A. Karim 2016. Effects of sugars on the gelation kinetis and texture of duck feet gelatin. J. Food Hydrocoll 58: 267275.

Marzuki, A., E. Pakki, dan F. Zulfikar. 2011. Ekstraksi dan penggunaan gelatin dari limbah tulang ikan bandeng (Chanos chanos forskal) sebagai emulgator dalam formulasi sedian emulsi. Majalah Farmasi dan Farmokologi 15: 63-68.

Mokoolang, S., M. Sompie, dan I. Wahyuni., 2019. Pengaruh konsentrasi Larutan kalsium hidroksida $\left(\mathrm{Ca}(\mathrm{OH})_{2}\right.$ gelatin kulit sapi terhadap karakteristik fisik dan kimia. J. AgriSosio Ekonomi 15 (3): 217-224.

Munyonga, J. H., C. G. B Cole and K.G. Doudu. 2004. Ekstraction and physic-chemicel characterization of Nile Pereh (Lestesnilation) skin and bone gelatin. Food Hydrocollids 18: 581-592.

Oktaviani, I., F. Perdana, dan A.Y. Nasution. 2017. Perbandingan sifat gelatin yang berasal dari kulit ikan patin (pangasius hypophthalmus) dan gelatin yang berasal dari kulit ikan komersial. JOPS. Vol 1(1): 1-8

Pantow, M.L., M. Sompie, A. Dp. Mirah dan L. Ch. M. Karisoh. 2016. Pengaruh konsentrasi asam asetat terhadap karakteristik kulit kaki ayam. Zootec 36 (1): 23-32.

Rares, R., M. Sompie, A. Dp. Mirah, J. A.D. Kalele. 2017. Pengaruh waktu perendaman dalam larutan asam asetat $\left(\mathrm{CH}_{3} \mathrm{COOH}\right)$ terhadap karakteristik fisik dan kimia gelatin ceker ayam. Zootec 37 (2) : 268-275.

Said, M. I., S. Triatmojo, Y. Erwanto, and A, Fudholi., 2011. Characteristics of goat skin gelatin that produced through acid and alkali process. Agritech Journal 31(3) : 190-200

Said, M. I. 2012. Optimasi Produksi Gelatin Kulit Kambing sebagai bahan Baku Edible Film untuk 
Bahan Pengemas Kapsul. Disertasi. Fakultas Peternakan. Universitas Gadjah Mada. Yogyakarta.

Schrieber, R. dan H. Gareis. 2007. Gelatine Handbook, Theory and Industrial Practice. WILEY-VCH Verlag $\mathrm{GmbH} \&$ Co.KGaA, Weinheim.

Setiawati, I. H. 2009. Karakterisasi Mutu Fisika Kimia Gelatin Kulit Ikan Kakap Merah (Lutjanus sp) hasil proses perlakuan asam. Skripsi. Bogor (ID): Institut Pertanian Bogor

Sompie, M., S. Triatmojo, A. Pertiwiningrum, dan Y. Pranoto. 2012. The effect of animal age and acetic concentration on pigskin gelatin characteristics. J. Indonesian Tropical Animal Agriculture 37(3): $176-182$.

Sompie, M. dan D. Rembet. 2017. The characteristic of pigskin gelatin produced from combination of acetic acid concentration and soaking time. Proceeding of the $15^{\text {th }}$ Asian Conference on Food Science and Technology (2): 366-370.

Sompie, M., S. E. Surtijono, J.W. Pontoh, N. Lontaan. 2015. Effect of acetic acid concertration and temperature extraction on physical and chemical properties of pigskin gelatin. Procedia Food Science, 3 (1): 383 388.

Sompie, M., S.E Siswosubroto, G.D Rembet, dan J.W. Ponto, 2019. Effect of different type of acid solvent on functional and microbiological properties of chicken claw gelatin. IOP Conf. Ser.: Earth Environ. Sci. 387012128
Sompie, M., R.M. Tinangon, S.E. Surtijono, dan M. I. Said., 2020. Effect of long-time immersion in edible film solution from local chicken claw on the physical and chemical properties of chicken meat.IOP Conf. Ser.: Earth Environ. Sci. 492 (2020) 012056

Steel, R.G. dan Torrie. 1995. Prinsip dan Prosedur Statistik. Gramedia Pustaka Utama. Jakarta

Sugihartono. 2014. Kajian gelatin dari kulit sapi limbah sebagai renewable flocculants untuk proses pengolahan air. J. Industri Res. 8: 179-190.

Ward, A. G. and A. Courts. 1997. The Seince and Techonology of Gelatin. Academis Press. New York

Wulandari, A., Supriadi, B. Purwanto. 2013. Pengaruh defating dan suhu ekstraksi terhadap karakteristik fisik gelatin tulang ikan babus. Jurnal Fishtech 2(1): $38-45$

Yuniarifin, H., V. P. Bintoro, dan A. Suwarastuti 2006. Pengaruh berbagai kosentrasi asam fosfat pada proses perendaman tulang sapi terhadap rendemen, kadar abu dan viskositas gelatin. J. Indonesia Trop. Anim. Agric. 31: 55-61.

Yusnaini, 2003. Kuantitas dan kualitas gelatin kulit kaki itik melalui proses asam dan basa dengan lama perendaman yang berbeda. Tesis. Program Pasca, Sarjana Universitas Hassanudin Makasar. 